\title{
PERANCANGAN PENGEMBANGAN TOKOH MANIK ANGKERAN UNTUK MEDIA GAME INTERAKTIF : CERITA TERPISAHNYA JAWA DAN BALI BERBASIS ANDROID
}

\author{
I Dewa Gede Agung Pandawana ${ }^{1)}$ I Nyoman Agus Suarya Putra ${ }^{2)}$ \\ Program Studi Teknik Informatika ${ }^{1)}$ 2) \\ STMIK STIKOM Indonesia, Denpasar, Bali \\ vandawaa@yahoo.com ${ }^{1)}$ nyomansuarya@ stiki-indonesia.ac.id ${ }^{2)}$
}

\begin{abstract}
Ancient stories often known as legends or folklore give philosophy, meaning and moral values about good and bad life. Folk stories are often told by parents to their children at bedtime. This is able to increase imagination, curiosity of children, thinking patterns and behavior of children towards the good. But with the development of technology, folklore began to be forgotten and began to be replaced by television and gadget media. This study aims to help mediate Balinese folklore into Android-based games in the hope that can make folktales more interesting and able to convey the moral message, traditions and local wisdom of Bali. The Balinese folklore raised is a story about Manik Angkeran which tells the story of the separation of the islands of Bali and Java. This first phase of the research focused on the character design stage and the character movements of Manik Angkeran and it's supporting characters designed based on the cultural philosophy of the regions of Bali and Java. The results of this study are to implement the Manik Angkeran and supporting characters in the form of moving characters on Android devices. Based on the results of BlackBox testing on 3 different Android devices, this first stage game shows the functionality that is expected, and the sharpness of the image is quite clear even though each device has a different resolution.
\end{abstract}

Keywords: Design, Game, Manik Angkeran, Android

\begin{abstract}
ABSTRAK
Cerita zaman dahulu yang sering dikenal dengan legenda atau cerita rakyat memberi filosofi, makna dan nilai moral tentang kehidupan yang baik dan buruk. Cerita rakyat sering diceritakan oleh orang tua kepada anaknya disaat menjelang tidur. Hal ini mampu meningkatkan imajinasi, rasa ingin tahu anak, pola fikir serta tingkah laku anak-anak kearah yang baik. Namun dengan semakin berkembangnya zaman dan teknologi cerita rakyat mulai dilupakan dan mulai tergantikan oleh media televise dan gadget. Penelitian ini bertujuan untuk membantu memediasi cerita rakyat Bali ke dalam bentuk game berbasis Android dengan harapan dapat mengemas cerita rakyat agar lebih menarik dan mampu menyampaikan pesan moral, tradisi dan kearifan lokal Bali. Cerita rakyat Bali yang diangkat adalah cerita tentang Manik Angkeran yang mengisahkan terpisahnya Pulau Bali dan Pulau Jawa. Pada penelitian tahap pertama ini difokuskan pada tahap perancangan karakter dan gerak karakter dari Manik Angkeran serta karakter pendukungnya yang dirancang berdasarkan dari filosofi budaya daerah Bali dan Jawa. Hasil dari penelitian ini adalah mengimplementasikan karakter Manik Angkeran dan karakter pendukungnya ke dalam bentuk karakter bergerak pada perangkat Android. Berdasarkan hasil pengujian BlackBox pada beberapa perangkat Android yang berbeda, game tahap pertama ini menunjukkan fungsionalitas yang sesuai dengan yang diharapkan serta tingkat ketajaman gambar yang cukup jelas walaupun setiap perangkat memiliki resolusi yang berbeda.
\end{abstract}

Kata Kunci : Rancang bangun, Game, Manik Angkeran, Android

\section{PENDAHULUAN}

Gunung Agung adalah gunung terbesar di pulau Bali. Banyak cerita dibalik kemegahannya. Salah satunya adalah cerita rakyat tentang terpisahnya pulau Jawa dan pulau Bali mengandung banyak pesan moral yang bernilai positif bagi anak anak. Nilainilai positif tersebut akan secara otomatis tersalurkan kepada anak-anak ketika mereka mendengarkan cerita yang menarik. Pesan yang disampaikan dalam cerita rakyat dapat 
memberi petunjuk tentang tingkah laku dalam masyarakat, ajaran baik dan buruk, kegembiraan, kesedihan, serta derita. Dengan pesan-pesan moral yang bernilai positif diharapkan dapat melatih perasaan emosi dan perkembangan dalam proses pembentukan watak seorang anak apalagi di zaman global sekarang ini.Watak anak-anak sudah di pengaruhi oleh hal-hal negatif yang tersebar di media sosial yang bersifat digital. Hal-hal tersebut dapat kita lihat di media sosial dimana hampir setiap harinya muncul berbagai berita dan informasi mengenai penyimpangan moral dan nilai-nilai positif dalam kehidupan yang dilakukan oleh anak - anak dibawah umur.

Pada zaman dahulu cerita rakyat sering diceritakan oleh orang tua kepada anaknya disaat menjelang tidur. Imajinasi seorang anak berkembang ketika mendengar sebuah cerita. Anak-anak akan membayangkan tokoh, tempat, dan seperti apa peristiwa terjadi. Hal ini mampu meningkatkan imajinasi dan rasa ingin tahu anak. Namun dengan semakin berkembangnya zaman dan teknologi cerita rakyat mulai dilupakan. Cerita yang biasanya diceritakan oleh orang tua kepada anaknya mulai tergantikan oleh media telivisi, dan gadget. Dengan kata lain tayangan pada media televisi, dan gadget pada zaman sekarang sangat mempengaruhi pemikiran dan polapikir anak-anak dibawah umur namun seperti yang kita ketahui tayangan-tayangan yang ada di televisi hampir tidak ada yang mencerminkan nilainilai positif, rata-rata semua hanya mempertontonkan hal-hal yang bersifat hiburan semata. Dengan tayangan yang kurang mendidik tersebut, pola fikir serta tingkah laku anak-anak di zaman sekarang menjadi berubah dan kurang memiliki nilainilai moral, nilai kesopanan, serta rasa cinta terhadap bahasa sendiri. Hal tersebut dapat dibuktikan dari artikel-artikel yang membahas mengenai perilaku anak-anak dibawah umur yang semakin menyimpang dari hal-hal positif.

Melalui data-data dari Pusat
Pelayanan Terpadu Pemberdayaan
Perempuan Dan Anak (P2TP2A) Denpasar,
mengenai jumlah kasus yang terjadi pada
anak baik sebagai pelaku, maupun korban
dari tahun 2014 sampai dengan juni 2016
mengalami peningkatan. Selain itu
berdasarkan hasil wawancara yang
dilakukan penulis kepada Ketua P2TP2A
yang membenarkan bahwa mental dan

karakter anak-anak usia dini sangat rentan dan rawan terpengaruh hal-hal negatif, hal tersebut dikarenakan kebanyakan orang tua saat ini terlalu mementingkan pekerjaannya sehingga kurangnya waktu untuk menemani dan memperhatikan perkembangan anak, selain itu tayangan-tayangan pada televisi juga kurang memberikan contoh-contoh yang mencerminkan kecintaan terhadap budaya lokal.

Berdasarkan data kuisioner dari sebuah penelitian dari Batuaya ( 2017 ) yang telah disebar kepada orang tua yang memiliki anak kelas IV SD di SDN 1 Semarapura Tengah, daerah klungkung dengan hasil bahwa memang benar anakanak mereka cenderung lebih menyukai animasi luar negeri dan mengikuti bahasa, adegan pada film tersebut. Sehingga gaya berbicara anak-anak saat ini kurang mencerminkan kecintaan terhadap bahasa sendiri, dan budaya lokal khususnya di daerah Bali.

Beberapa animasi di stasiun televisi di Indonesia telah menanyangkan beberapa film favorit anak, contohnya "Upin dan Ipin", "Boboboy", serta "Sang Kancil". Tayangan animasi tersebut membuat anakanak dengan mudah memahami maksud dari film animasi tersebut dikarenakan keunggulan dari film animasi 2 dimensi yaitu mampu menampilkan suatu bentuk yang tidak dapat ditampilkan dengan nyata, selain itu animasi 2 dimensi juga mampu menampilkan bentuk yang imajinatif. Namun dari segi bahasa, dan penyampaian pesan moral film-film diatas kurang menekankan pada nilai-nilai kecintaan terhadap bahasa sendiri baik itu bahasa Indonesia, maupun bahasa daerah sendiri. Anak-anak sangat menggemari tayangan tersebut namun mereka juga meniru bahasa yang dipergunakan pada film atau tayangan tersebut, hal ini membuktikan bahwa film animasi 2 dimensi yang dipertontonkan terhadap anak-anak cukup memberikan pengaruh terhadap pola pikir dan tingkah laku anak-anak tersebut, dapat dikatakan demikian karena faktanya setelah menonton tayangan tersebut anak-anak langsung dapat menceritakan kembali fenomena-fenomena yang terdapat pada film animasi 2 dimensi tersebut, dan mereka juga langsung mempergunakan bahasa-bahasa pada film animasi 2 dimensi tersebut untuk bercanda dan berkomunikasi dengan orang-orang sekitarnya.Disisi lainnya, teknologi digital seperti game pada android mampu 
mempengaruhi prilaku pada anak anak.Game yang lagi hits atau tren belakangan ini adalah mobile legend. Anak anak sangat menyukai game ini. Tokoh tokoh dalam game mampu diceritakan oleh anak anak dengan detail. Kekuatan, senjata, dan lain sebagainya. Namun game ini hanya bersifat hiburan semata tanpa mampu memberikan nilai moral atau nilai luhur budaya bangsa.Ketertarikan anak anak terhadap gambar tokoh dalam game menjadikan perubahan tingkah laku yang mengarah pada kekerasan fisik, mental dan pergeseran nilai moral. Jika hal ini dibiarkan tanpa adanya solusi maka ke depannya akan muncul tokoh tokoh penggerak yang mengandalkan kekerasan fisik, muncul tokoh yang berkepribadian negative sehingga takkan pernah ada yang menjunjung tinggi budaya bangsa Indonesia.

Cerita Manik Angkeran adalah sebuah cerita kuno budaya bangsa yang menceritakan tentang seorang anak yang durhaka kepada orang tuanya, seorang anak yang gemar berjudi, mencuri dan bermain main hingga pada akhir ceritanya iya mencuri dan memotong ekor naga besukih di Gunung Agung . Akibat perbuatannya iyapun tewas. Karena bantuannya ayahnya yang bernama Begawan Sidimantra maka manik angkeran selamat atas restu dari naga Besukih. Pada akhirnya agar manik angkeran tak berulah lagi maka oleh Begawan Sidimantra, dipisahkanlah pulau Jawa dengan pulau Bali. Dalam penelitian ini akan diulas tentang tokoh Manik Angkeran yang selanjutkan akan dituangkan pada sebuah game interaktif berbasis android. Game ini nantinya mampu menyampaikan tentang cerita dari Manik Angkeran, Filosofi tokoh dalam budaya lokal,nilai nilai moral, serta tradisi. Game akan direncanakan dirancang dalam beberapa tahap yaitu : 1 . Tahap perancangan Karakter, 2. Tahap Perancangan Setting dan Level , 3. Tahap Penyempurnaan dan Scooring. Pada tahap pertama perancangan game di mulai dari tahap perancangan Karakter manik Angkeran. Karakter Manik Angkeran dirancang dari filosofi budaya daerah bali dan jawa dengan meriset terhadap kehidupan sosiologis zaman peradaban. Karakter mengambil pola tokoh yang khas dari rancangan yang baru dan memiliki Karakter budaya dari Indonesia.

\section{TINJAUAN PUSTAKA \\ Cerita Rakyat}

Cerita rakyat mengisahkan suatu kejadian di suatu tempat atau asal muasal suatu tempat. Fungsi cerita rakyat selain sebagai hiburan, juga sebagai suri tauladan terutama cerita yang mengandung pesan pendidikan moral (Gusnetti and Isnanda, 2016)

\section{Multimedia}

Multimedia merupakan penggunaan komputer untuk menyajikan dan menggabungkan teks, suara, gambar, animasi, audio, dan video dengan alat bantu (tool) dan koneksi (link) sehingga pengguna dapat melakukan navigasi, berinteraksi, berkarya, dan berkomunikasi. Multimedia sering digunakan dalam informatika. Selain di dunia informatika, multimedia juga diadopsi oleh dunia game, dan juga untuk membuat website (Senn, 1998,15).

\section{Desain Komunikasi Visual}

Di Indonesia kegiatan desain dikelompokkan menjadi tiga bagian besar; Desain Produk Industri (Industrial Design), Desain Komunikasi Visual (Visual Communication Design), dan Desain Interior (Interior Design). Dari tiga bagian besar tersebut, pada penelitian ini hanya akan dibahas tentang Desain Komunikasi Visual, yaitu; profesi yang mengkaji dan mempelajari desain dengan berbagai pendekatan dan pertimbangan, baik yang menyangkut komunikasi, media, citra, tanda maupun nilai. Dalam buku berjudul Desain Komunikasi Visual yang ditulis oleh Supriyono, disebutkan bahwa desain komunikasi visual memiliki peran mengkomunikasikan pesan atau informasi kepada pembaca dengan berbagai kekuatan visual, seperti typography, ilustrasi, warna, garis, lay out, dan sebagainya dengan bantuan teknologi (Supriyono, 2010).

Pengertian desain komunikasi visual sebagai desain yang mengkomunikasikan informasi dan pesan yang ditampilkan secara visual.Desainer komunikasi visual berusaha untuk mempengaruhi sekelompok pengamat. Mereka berusaha agar kebanyakan orang dalam target group (sasaran) tersebut memberikan respon positif kepada pesan visual tersebut. Oleh karena itu desain komunikasi visual harus komunikatif, dapat dikenal, dibaca dan dimengerti oleh target group tersebut (Cenadi, 1999, 4) 


\section{Games}

Game adalah sebuah sistem yang melibatkan pemain dalam sebuah konflik buatan, yang ditentukan oleh aturan, dan menghasilkan hasil yang terukur (Salen dan Zimmerman, 2003, 96).

Game adalah sebuah permainan komputer interaktif yang dikendalikan oleh mikroprosesor. Game atau dalam bahasa indonesia disebut juga permainan tidaklah sembarang, dimana pada sebuah permainan biasanya terdapat aturan yang harus dipahami dan diikuti oleh penggunanya. Game juga terbagi dalam beberapa jenis game yang berbeda-beda yang masingmasingnya mempunyai ciri khas tersendiri (Henry, 2010).

\section{METODOLOGI PENELITIAN \\ Perancangan}

Pada penelitian tahap pertama ini difokuskan pada tahap perancangan karakter dan gerak karakter dari Manik Angkeran serta karakter pendukungnya yang dirancang berdasarkan dari filosofi budaya daerah Bali dan Jawa. Perancangan Karakter Manik Angkeran dalam game interaktif terpisahnya pulau Jawa dengan Pulau Bali akan dirancang dalam beberapa tahapan. Tahapan pertama adalah mengumpulan literasi literasi visual, melakukan riset ilustrasi tokoh untuk memahami dan membentuk tokoh yang dirancang sesuai tujuan yang diharapkan. Tahapan kedua adalah adalah menterjemahkan sketsa gambar ke digital art berdasarkan pola hasil pengembangan atau inovasi. Membuat beberapa gambar sebagai bagian adegan dalam menyusun animasi. Tahapan ketiga adalah merancang animasi Karakter Manik Angkeran untuk game android. Adapun beberapa karakter yang dibuat meliputi : Karakter Manik Angkeran sebagai karakter utama, Karakter Naga Basuki karakter kedua, serta Karakter Raksasa dan Karakter Babi sebagai karakter pendukung sebagai musuh. Adapun beberapa animasi karakter yang akan dibuat adalah animasi karakter dengan beberapa gerakan. Gerakan tersebut diantaranya seperti : gerakan berjalan, gerakan berlari (kanan kiri lurus) dan gerakan perang menggunakan tangan yang menggunakan senjata.

Masing-masing gerakan ini dibuat menggunakan metode Animasi Sprite. Animasi sprite adalah salah satu cara untuk membuat animasi yang serupa dengan teknik animasi tradisional, yaitu dengan menjejerkan secara berurutan setiap gambar gerakan dari sebuah objek atau karakter pada sebuah kanvas dari kiri ke kanan. Urutan sejumlah gambar ini dapat disimpan dalam 1 file, biasanya file berekstensi PNG. File animasi sprite ini berisi sejumlah urutan gerakan karakter sekaligus baik dari gerakan berjalan, berlari, menendang dan memukul. Nantinya, file ini akan dibaca dan diterjemahkan oleh engine bernama Corona SDK. Dimana dengan menggunakan engine ini, file animasi sprite akan dibaca, diterjemahkan dan dapat menampilkan masing-masing gerakan dari karakter sesuai dengan keperluan. Adapun rancangan tampilan dari aplikasi yang dibuat pada penelitian ini adalah terdiri dari Menu Utama, Menu Pilih Karakter, Menu Tampilan Animasi dan Menu Informasi.

\section{HASIL DAN PEMBAHASAN}

\section{Desain Karakter}

Pembuatan desain karakter, diawali dengan Sketsa Dasar, dimana penulis bermaksud mencari persepsi gambar yang sesuai atas Karakter yang diinginkan dalam perancangan. Dari riset yang dilaksanakan, serta mengumpulkan sumber refrensi yang ada maka, berikutnya dibuat sebuah ide perancangan melalui sketsa yang dilakukan secara manual. Pemahaman yang ada pada kharater yang diinginkan adalah sesosok laki laki muda bernama Manik Angkeran, dengan desain yang berciri khas daerah namun tak lepas dari budaya Bali. Gambar 1 hingga gambar 3 berikut ini adalah transformasi hasil riset karakter dari bentuk sketsa dasar dan hasil jadi setelah diwarnai.
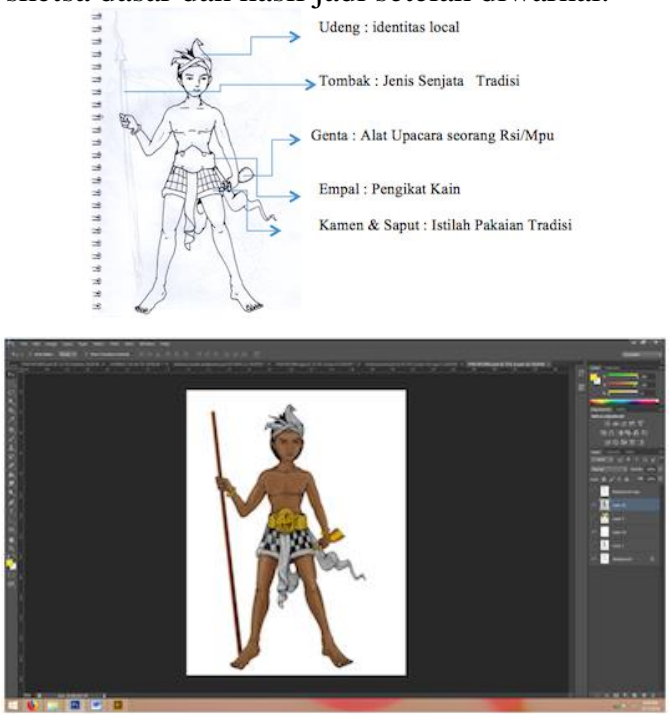

Gambar 1. Perbandingan Sketsa Dasar dan Pewarnaan Karakter Manik Angkeran 


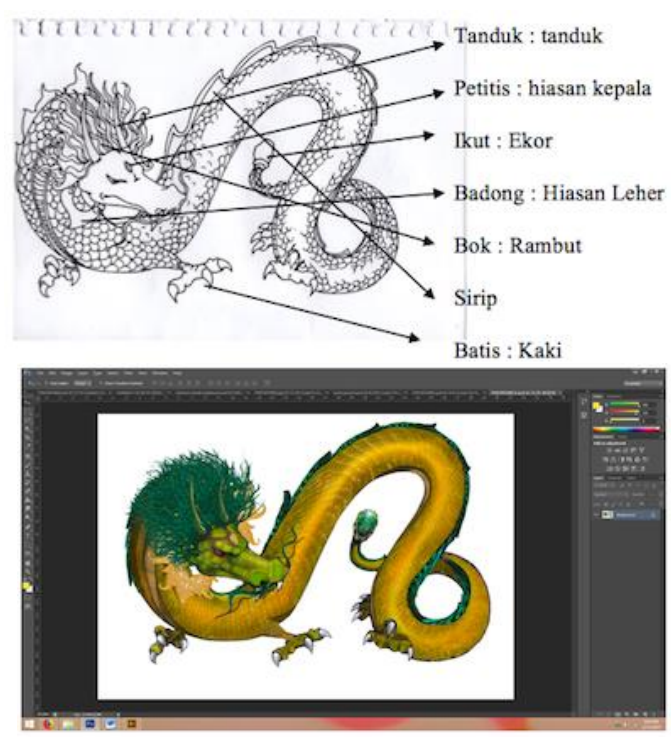

Gambar 2. Perbandingan Sketsa Dasar dan Pewarnaan Karakter Naga Basukih
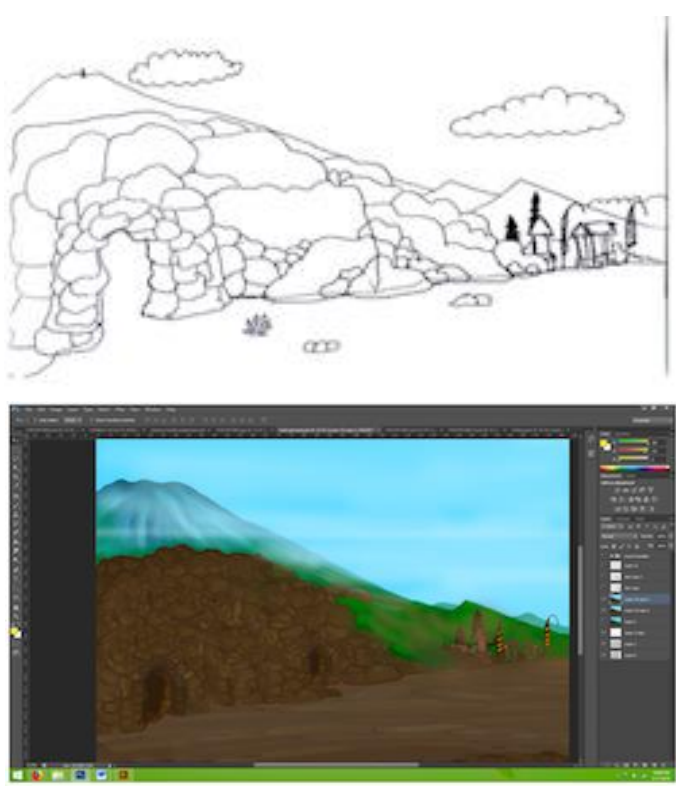

Gambar 3. Perbandingan Sketsa Dasar dan Pewarnaan Lanskap Latar Game

\section{Penganimasian Gerak Karakter}

Proses selanjutnya adalah merancang aset untuk dianimasikan. Untuk mempermudah proses animasi, karakter aset dibuat pada Adobe Ilustrator. Hal ini dilakukan untuk mempermudah kombinasi pewarnaan antara Karakter di Adobe Ilustrator dan Karakter setelah di bawa ke Adobe Photoshop. Masing-masing gerakan karakter ini dibuat menggunakan metode
Animasi Sprite. Animasi sprite adalah salah satu cara untuk membuat animasi yang serupa dengan teknik animasi tradisional, yaitu dengan menjejerkan secara berurutan setiap gambar gerakan dari sebuah objek atau karakter pada sebuah kanvas dari kiri ke kanan. Setelah karakter jadi, kemudian disimpan dalam format PNG, untuk nantinya dapat digunakan dalam engine pembuat game Corona SDK. Adapun untuk karakter yang digerakkan, terdapat 4 karakter yaitu karakter Manik Angkeran, Naga, Raksasa dan Babi. Karakter Manik Angkeran merupakan karakter utama dari game, sedangkan karakter Naga, Raksasa dan Babi merupakan karakter yang menjadi musuh dari Manik Angkeran
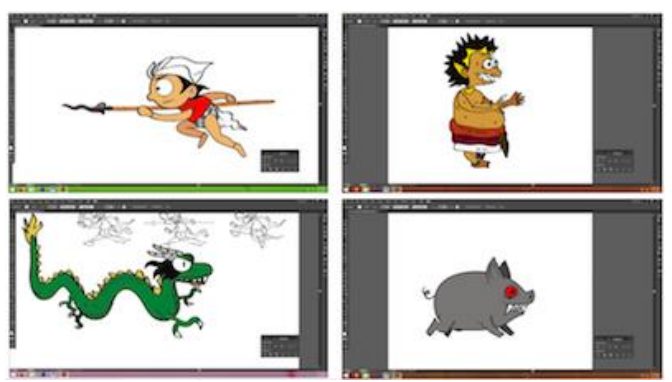

Gambar 4. Pewarnaan dan Penganimasian Gerak Karakter Pada Game

\section{Tampilan Game Manik Angkeran}

Pada bagian ini akan dijelaskan realisasi dan implementasi dari perancangan antarmuka sebelumnya menjadi tampilan aplikasi pada perangkat bergerak handphone. Adapun mode tampilan yang digunakan adalah mode Lanskap untuk memudahkan navigasi dari pengguna. Untuk kecepatan penganimasian per detiknya, pada game ini digunakan ukuran 30 frame per detiknya.

Pada halaman awal pada saat aplikasi diluncurkan, ditampilkan Logo dari STMIK STIKOM Indonesia dengan menggunakan efek animasi memudar dari hilang hingga tampil jelas dan sebaliknya. Berikut adalah tampilan dari Halaman Logo Institusi yang terdapat pada gambar 5 berikut. 


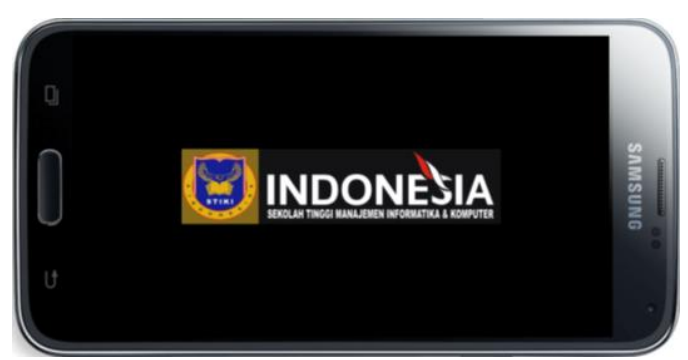

Gambar 5. Tampilan Halaman Logo Institusi

Selanjutnya adalah tampilan Menu Utama yang merupakan menu awal yang menampilkan gambar latar / background dari Manik Angkeran dan Naga Basuki yang mewakili dari aplikasi ini. Selain itu, terdapat Judul aplikasi di bagian bawah tengah serta 2 tombol navigasi. Kedua tombol ini adalah Tombol Pilih Karakter dan Tombol Informasi, yang setelah diklik akan menampilkan Halaman Pilih Karakter atau pun Halaman Informasi. Gambar 6 berikut adalah tampilan dari Menu Utama.

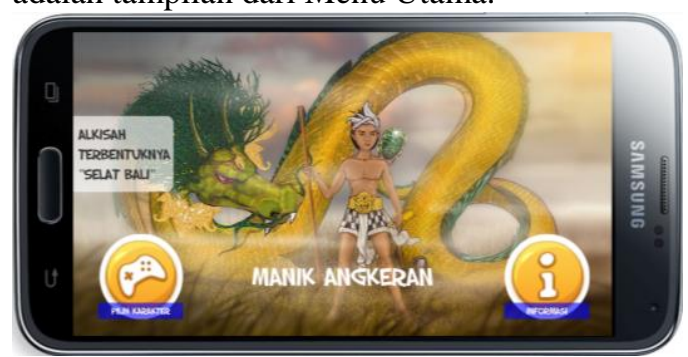

Gambar 6. Tampilan Menu Utama

Tampilan selanjutnya adalah tampilan Menu Pilih Karakter, dimana pengguna dapat memilih salah satu dari 4 karakter yang ingin ditampilkan, yaitu : Manik Angkeran, Naga Basuki, Raksasa dan Babi. Gambar 7 berikut ini adalah tampilan dari Menu Pilih Karakter.

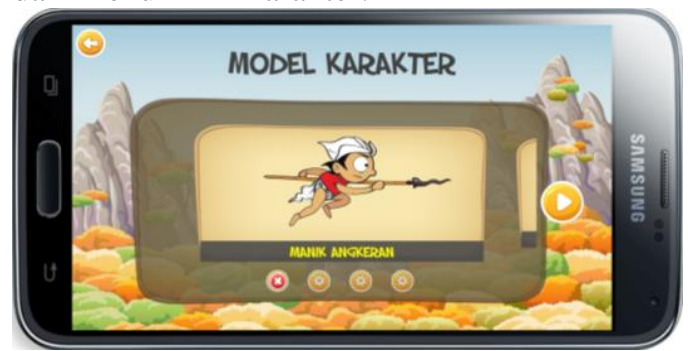

Gambar 7. Tampilan Menu Pilih Karakter

Setelah pengguna memilih salah satu karakter yang ingin dilihat, maka akan muncul Tampilan Animasi yang merupakan tampilan utama pada aplikasi ini. Pada halaman ini pengguna dapat melihat gerakan dari karakter yang dipilih. Pada halaman ini, terdapat perbedaan dari tampilan yang ada, berdasarkan dari karakter yang dipilih. Jika pada menu sebelumnya yang dipilih adalah Karakter Manik Angkeran, maka pada tampilan animasi ini akan dilengkapi dengan 4 tombol navigasi Kanan, Kiri, Atas dan Bawah yang berfungsi untuk menggerakkan karakter Manik Angkeran sesuai dengan tombol navigasi yang dipilih. Pada tampilan ini, karakter Manik Angkeran diilustrasikan mengunakan senjata yang disiapkan untuk menyerang karakter musuh yang akan keluar dari Goa-goa yang ada maupun dari udara. Berikut adalah tampilan halaman animasi dengan karakter Manik Angkeran pada gambar 8 .

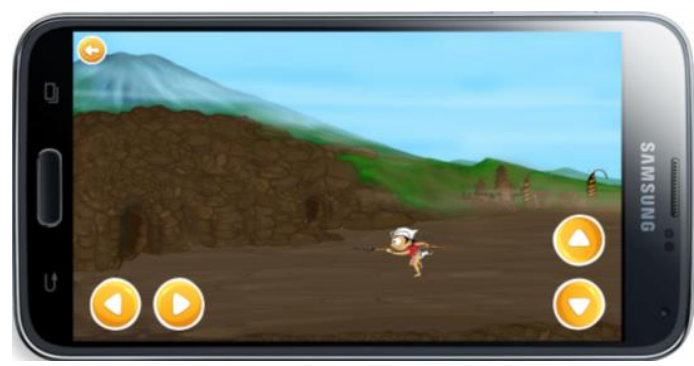

Gambar 8. Menu Tampilan Animasi Pada Karakter Manik Angkeran

Tampilan lain dari tampilan animasi ini adalah jika karakter yang dipilih adalah karakter seperti Naga Basuki, Raksasa dan Babi. Untuk tampilan dari ketiga karakter ini, tidak dimunculkan tombol navigasi, melainkan karakterkarakter ini akan langsung ditampilkan pada aplikasi sesuai gerakan animasi yang disiapkan serta dalam jumlah tertentu. Masing-masing karakter ini akan bergerak dari Kiri ke Kanan yang nantinya dimaksudkan untuk menjadi lawan dari Manik Angkeran. Gambar 9, gambar 10 dan gambar 11 berikut adalah tampilan dari tampilan animasi dari karakter Naga Basuki, Raksasa dan Babi.

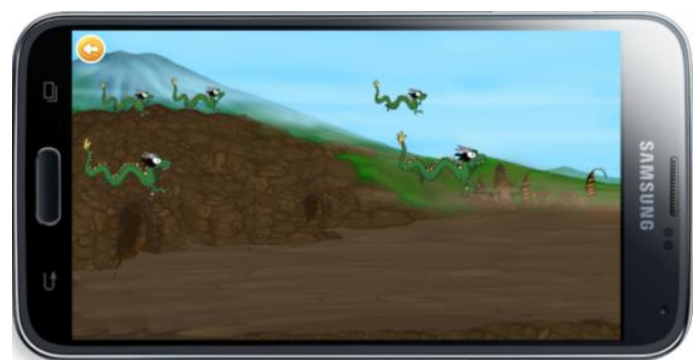

Gambar 9. Menu Tampilan Animasi Pada Karakter Naga Basuki 


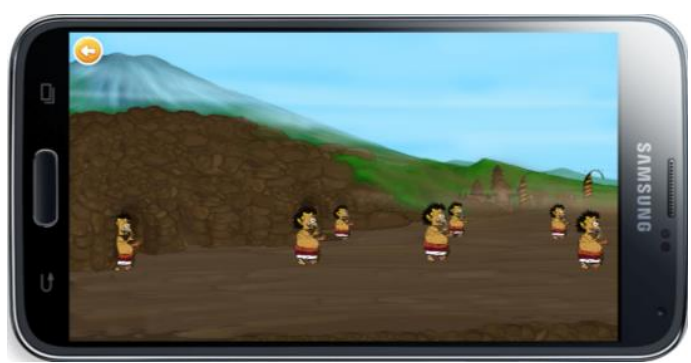

Gambar 10. Menu Tampilan Animasi Pada Karakter Raksasa

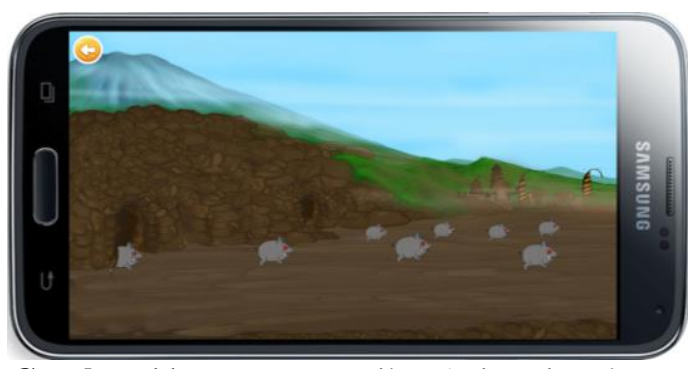

Gambar 11. Menu Tampilan Animasi Pada Karakter Babi

Tampilan terakhir adalah tampilan Menu Informasi. Pada tampilan ini ditampilkan informasi mengenai aplikasi yang dibuat. Berikut adalah tapilan dari Menu Informasi yang dapat dilihat pada Gambar 12.

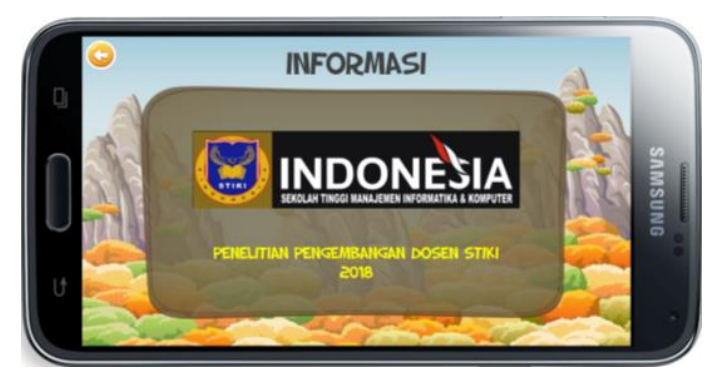

Gambar 12. Tampilan Menu Informasi

\section{Pengujian Black Box}

Pada tahap pengujian, perangkat Android yang digunakan adalah tiga perangkat yang berbeda, baik dari segi resolusi layar, versi sistem operasi, maupun kemampuan perangkat keras. Adapun ketiga perangkat tersebut adalah Samsung Galaxy Grand versi Android 4.1.2 dengan resolusi layar 480 x 800 pixel, Huawei Honor 4C versi android 4.4.2 dengan resolusi layar 720 x 1280 pixel, dan Huawei Media Pad T1 Tablet versi android 4.4.2 dengan resolusi layar 600 x 1024 pixel. Pengujian dilakukan untuk mengetahui apakah funsionalitas secara umum dari aplikasi sudah berjalan sesuai yang direncanakan dan tampilan game tetap stabil dan gambar tidak buram atau pecah pada semua perangkat dengan resolusi layar yang berbeda. Tabel 1 menunjukkan hasil pengujian Black box secara umum telah sesuai dengan hasil yang diharapkan dan tampilan yang jelas, stabil dan gambar tetap tajam atau tidak buram.

Secara keseluruhan, resolusi tampilan pada setiap perangkat yang diujicobakan memiliki resolusi dan tingkat ketajaman gambar yang cukup jelas walaupun setiap perangkat memiliki resolusi yang berbeda. Hal lainnya, dalam pengujian fungsional dari masing-masing tombol, semuanya berjalan dengan baik sesuai yang diinginkan. Dalam hal tampilan animasi, animasi yang tampil pun sudah sesuai dengan hasil yang diharapkan. Hanya saja terlihat cukup jelas perbedaan dari segi kecepatan dari masing-masing perangkat dalam membuat dan menampilkan tampilan menu. Hal ini dapat terlihat terutama pada Menu Tampilan Animasi yang mengharuskan perangkat membuat banyak file gambar dengan ukuran yang cukup besar secara sekaligus. 
Tabel 1. Skenario dan Hasil Pengujian Blackbox

\begin{tabular}{|c|l|l|c|}
\hline No & \multicolumn{1}{|c|}{ Skenario Pengujian } & \multicolumn{1}{|c|}{ Hasil Yang Diharapkan } & $\begin{array}{c}\text { Hasil } \\
\text { Pengujian }\end{array}$ \\
\hline 1 & $\begin{array}{l}\text { Mengakses Menu Utama saat awal } \\
\text { aplikasi berjalan maupun dari menu lain. }\end{array}$ & $\begin{array}{l}\text { Menampilkan Menu Utama serta } \\
\text { animasi gerakan seluruh } \\
\text { komponennya. }\end{array}$ & Valid \\
\hline 2 & $\begin{array}{l}\text { Mengakses Menu Informasi dari Menu } \\
\text { Utama }\end{array}$ & $\begin{array}{l}\text { Menampilkan Menu Informasi serta } \\
\text { info terkait aplikasi. }\end{array}$ & Valid \\
\hline 3 & $\begin{array}{l}\text { Mengakses Menu Pilih Karakter dari } \\
\text { Menu Utama }\end{array}$ & $\begin{array}{l}\text { Menampilkan Menu Pilih Karakter } \\
\text { dan menu yang dapat digeser maupun } \\
\text { diklik. }\end{array}$ & Valid \\
\hline 4 & $\begin{array}{l}\text { Mengakses Menu Tampilan Animasi } \\
\text { dari Menu Pilih Karakter }\end{array}$ & $\begin{array}{l}\text { Menampilkan Menu Tampilan } \\
\text { Animasi serta animasi gerakan } \\
\text { seluruh komponennya. }\end{array}$ & Valid \\
\hline 5 & $\begin{array}{l}\text { Mencoba masing-masing gerakan dari } \\
\text { animasi karakter Manik Angkeran }\end{array}$ & $\begin{array}{l}\text { Menampilkan gerakan masing- } \\
\text { masing animasi, sesuai dengan } \\
\text { tombol yang ditekan. }\end{array}$ & Valid \\
\hline 6 & $\begin{array}{l}\text { Mencoba menampilkan gerakan dari } \\
\text { animasi karakter Naga Basuki, Raksasa } \\
\text { dan Babi }\end{array}$ & $\begin{array}{l}\text { Menampilkan gerakan masing- } \\
\text { masing animasi }\end{array}$ & Valid \\
\hline 7 & $\begin{array}{l}\text { Menampilkan setiap tampilan dan } \\
\text { animasi gerakkan pada device dengan } \\
\text { resolusi layar yang berbeda. }\end{array}$ & $\begin{array}{l}\text { Menampilkan seluruh tampilan } \\
\text { dengan baik dengan gambar yang } \\
\text { jelas atau tidak buram. }\end{array}$ & Valid \\
\hline
\end{tabular}

\section{SIMPULAN}

Perancangan pengembangan tokoh Manik Angkeran untuk media game interaktif cerita terpisahnya Jawa dan Bali berbasis android ini telah berhasil dilakukan. Berdasarkan hasil pengujian Black Box seluruh fungsionalitas dari aplikasi telah berjalan dengan baik, ketajaman tampilan gambar pada perangkat handphone yang digunakan untuk pengujian sesuai dengan yang diharapkan. Hanya saja, pengaruh spesifikasi perangkat sangat mempengaruhi performa dari aplikasi. Semakin tinggi spesifikasi dari perangkat handphone, maka semakin baik pula tampilan serta kecepatan dari perangkat untuk membuat dan menampilkan gambar berukuran besar dengan jumlah banyak secara sekaligus.

\section{DAFTAR PUSTAKA}

[1] Cenadi, Christine Suharto. 1999. Elemen-elemen dalam Desain Komunikasi Visual. Nirmana Vol. 1, No. 1, Januari 1999: 1-11.

[2] Henry, Samuel. 2010 . Cerdas dengan Game : Panduan Praktis bagi Orangtua dalam Mendampingi Anak Bermain Game. Jakarta: Gramedia Pustaka Utama.

[3] Gusnetti, S., dan Isnanda, R. 2016. Struktur dan Nilai-Nilai Pendidikan Dalam Cerita Rakyat Kabupaten Tanah Datar Provinsi Sumatera Barat. Jurnal gramatika, vol. 2, no. 1, pp.128-140.

[4] Salen, K., dan Zimmerman, E. 2003. Rules of Play - Game Design Fundamental". Cambridge : MIT Press.

[5] Senn, James A. 1998. Information Technology in Business : Principles, Practices and Opportunities. 2nd Edition. Prentice Hall, New Jersey.

[6] Supriyono, Rakhmat. 2010. Desain Komunikasi Visual Teori dan Aplikasi. Yogyakarta: ANDI 